\title{
Density and reproductive success of Florida grasshopper sparrows following fire
}

\author{
MICHAEL F. DELANY, STEPHEN B. LINDA, BILL PRANTY, AND DUSTIN W. PERKINS
}

Authors are Wildlife Biologist and Biometrician, Florida Fish and Wildlife Conservation Commission, Wildlife Research Laboratory, Gainesville Fla. 32601; Avian Project Leader, Audubon of Florida, Tampa, Fla. 33619; and Ph.D. candidate, University of Maine, Orono, Me. 04684.

\begin{abstract}
Information on the response of the endangered Florida grasshopper sparrow (Ammodramus savannarum floridanus Mearns) to range management, especially prescribed fire, is needed to determine conservation strategies. Intensive management of grasslands for cattle grazing and conversion of grassland to other agricultural use is considered the greatest threat to the sparrow. Territory spot-mapping and estimates of reproductive success were examined in relation to time post-burn in managed cattle pastures at Avon Park Air Force Range, Highlands County, Florida from 1997-1999. We tested the hypothesis that sparrow density and reproductive success did not depend on time following fire. Contrary to previous work, there was no evidence that Florida grasshopper sparrow territory density depended on years post-burn $(P=0.842)$. The probability of reproductive success was significantly higher 0.5 year post-burn than at 1.5 years post-burn $(P<0.05)$ and 2.5 years post-burn $(P<0.01)$. No other significant differences were observed among years post-burn (P $>0.27$ for each pairwise comparison between years). No simple trend or highly significant polynomial relationship between reproductive success and territory density was indicated $(P>$ 0.41). Compared to other subspecies, Florida grasshopper sparrows exhibited relatively low density $(0.22$ territories/ha or less) and reproductive success $(20 \%)$. Our results suggest increased reproductive success at a population level 0.5 year following fire, and did not suggest an association between territory density and individual reproductive success. Additional information is needed on the effects of seasonality of fire on Florida grasshopper sparrows.
\end{abstract}

Key Words: Ammodramus savannarum floridanus, Florida prairie, prescribed fire

Declines in the abundance of some grassland birds in North America are attributed to habitat loss induced by changes in land management (Peterjohn and Sauer 1999). Grasshopper sparrows (Ammodramus savannarum Gmelin) are locally distributed in low to medium height grasslands throughout most of temperate North America, from Mexico to Ecuador, and the West Indies. Breeding bird surveys evince a decline in some populations (Vickery 1996). The Florida subspecies (A. s. floridanus Mearns) is endemic to the

This study was supported by Cooperative Agreement No. 14-45-0009-154 Research work order 175, funded by the U.S. Air Force through the Florida Cooperative Fish and Wildlife Research Unit.

Manuscript accepted 24 Oct 01.

\section{Resumen}

Se necesita información de la respuesta de la especie en peligro de extinción "Florida grasshopper sparrow" (Ammodramus savannarum floridanus Mearns) al manejo del pastizal, especialmente al fuego prescrito, para determinar estrategias de conservación. El manejo intensivo de los pastizales para apacentamiento de ganado y la conversión del pastizal a otros usos agrícolas se consideran como la mayor amenaza para el "Sparrow". De 1997 a 1999 el mapeo de manchas territoriales y estimaciones de éxito reproductivo se examinaron en relación al tiempo después de la quema, lo cual se realizó en potreros manejados para ganado en la Base Aérea Avon Park, en el condado Highlands, Florida. Probamos la hipótesis de que la densidad de "Sparrow" y el éxito reproductivo no depende del tiempo después de la quema. Contrario a trabajos previos, no hubo evidencia de que la densidad territorial del "Florida grasshopper sparrow" dependa de los años después de la quema $(P=0.842)$. La probabilidad de éxito reproductivo fue significativamente mayor 0.5 años que 1.5 años después de la quema $(P<0.05)$ y que 2.5 años después del fuego $(P<0.01)$. No se observaron otras diferencias significativas entre años después de la quema $(P>0.27$ para cada comparación de pares entre años). No se detectó $(P>0.41)$ una tendencia simple o una tendencia polinomial altamente significativa entre el éxito reproductivo y la densidad territorial. Comparado con otras subespecies, el "Florida grasshopper sparrows"mostró una densidad territorial relativamente baja $(0.22$ territorios/ha o menos) y un bajo éxito reproductivo (20\%). Nuestros resultados sugieren un mayor éxito reproductivo, a nivel de población, 0.5 años después del fuego y no sugieren una asociación entre la densidad territorial y el éxito reproductivo individual. Se necesita información adicional sobre los efectos de la estacionalidad del fuego en el "Florida grasshopper sparrows".

south-central, dry prairie region of the state and was classified as endangered because of its restricted distribution, loss of habitat, and population decline (U.S. Fish and Wildlife Service 1988). Breeding aggregations are known from only 6 locations and fewer than 1,000 birds may exist (Delany et al. 1999). Information on the sparrow's response to range management is needed before conservation strategies for the subspecies can be fully assessed (U.S. Fish and Wildlife Service 1988).

An examination of structural characteristics of occupied and abandoned territories indicated that Florida grasshopper sparrows cannot adapt to habitat perturbations that remove potential nest sites (bunch grasses and dwarfed shrubs) and bare-ground foraging areas (Delany and Linda 1994). Intensive management of 
grasslands for cattle grazing and conversion of grassland to other agricultural use is the greatest threat to the sparrow (U.S. Fish and Wildlife Service 1988). Improved pastures are created and maintained by mechanical clearing and planting bahia grass (Paspalum sp.), pangola grass (Digitaria sp.), American joint vetch (Aeshynomene americanus L.), and clover (Trifolium spp.) (Milleson et al. 1980, Delany and Linda 1994). Prairies also are plowed and planted with bahia grass for sod production. Shriver and Vickery (1999) estimated only $19 \%$ (156,000 ha) of the original dry prairie remained in central peninsular Florida.

The Florida grasshopper sparrow has benefitted from prescribed burning at some locations. Prescribed fire at 2-3 year intervals during the winter dormant season (December-March) is the most common practice used to improve prairie pastures for cattle grazing in Florida (Lewis 1964, Abrahamson and Hartnett 1990). Frequent burning also maintains vegetation in a sparse, early successional stage preferred by the sparrow (Delany et al. 1985). Increased densities of Florida grasshopper sparrows associated with time post-burn (Walsh et al. 1995) may be related to changes in prairie physiognomy following fire and have important management implications. However, population density estimates without demographic data may not be a reliable indicator of habitat quality (Van Horne 1983). We examined the density and reproductive success of Florida grasshopper sparrows in relation to time post-burn to assess the effects of prescribed burning, and tested the hypothesis that territory density and reproductive success did not depend on time following fire.

\section{Study Area}

The study area was a 700-ha prairie $\left(27^{\circ} 38.08^{\prime} \mathrm{N}, 81^{\circ} 19.30^{\prime} \mathrm{W}\right)$ on the U.S. Air Force Avon Park Range in Highlands County, Fla. The climate is humid subtropical (Chen and Gerber 1990). Mean annual temperature is $22^{\circ} \mathrm{C}$ with monthly mean temperatures ranging from $17^{\circ} \mathrm{C}$ in January to $28^{\circ} \mathrm{C}$ in August. Mean annual rainfall is $1,370 \mathrm{~mm}$, with most $(60 \%)$ precipitation associated with convective thunderstorms and tropical systems occurring from June to September (Carter et al. 1989). The topography is nearly level and the sandy soils (Malabar and Oldsmar series) are poorly drained (Carter et al. 1989). The grassland was dominated by wiregrass (Aristida beyrichiana Trin. and
Rupr.), bluestems (Andropogon spp.), yellow-eyed grass (Xyris spp.), saw palmetto (Serenoa repens W. Bartram, Small), dwarf live-oak (Quercus minima Sarg.), and shrubs; and included scattered cypress (Taxodium sp.) domes and small (4 ha or less) hypericum (Hypericum spp.) ponds. The study area was bordered by slash pine (Pinus elliottii Engelm.) plantations, opencanopy longleaf pine (P. palustris Mill.), introduced pastures (plowed and planted with non-native grasses), and freshwater marsh. Cattle grazed the study area at 1 animal per 8.7-28.3 ha with grazing periods of 21 days or less followed by longer periods of exclusion. Forage utilization during a grazing period was light. Four prairie pastures (165-324 ha) were burned with head fires (burned with the wind) on 3-year rotations between December and mid-March to enhance forage production and manage habitat for Florida grasshopper sparrows. Ordnance-ignited wildfires occur year-round.

\section{Methods}

\section{Sparrow Density and Reproductive Success}

The density of Florida grasshopper sparrow territories was determined using standard spot-mapping techniques (International Bird Census Committee 1970) on 12 study plots ( 8.5 to 20.0 ha, $\bar{x}=12.8$ ha) at least $50 \mathrm{~m}$ from non-prairie habitats and separated by at least $100 \mathrm{~m}$. Plots were the same as those used by Shriver and Vickery (2001). Plots were marked with $50 \mathrm{~m}$ grids of labeled wired flags. Spot-mapping periods of about 1 hour per plot were made by walking to each grid marker, with direction alternated between successive sur- veys. Observations of sparrow locations and reproductive success were recorded in reference to the grid markers. Surveys were conducted between sunrise and 1000 hours in the absence of rain and at wind velocities less than $11 \mathrm{~km} /$ hour. Plots were sampled 8-13 times each year at about 10 day intervals from 22 March-25 August, 1997-1999. Based on maximum territory size, male sparrows observed on different days more than $203 \mathrm{~m}$ apart were considered separate individuals (Walsh et al. 1995), and those exhibiting breeding behavior for at least 4 weeks were considered territorial (Vickery et al. 1992a). Locations of male sparrows were digitized and territories mapped with ArcView GIS software (ESRI 1990). Density was considered the number of territories per ha and included only those that were at least $50 \%$ within a plot. A territorial male was deemed to have reproduced successfully if fledglings were observed or adults carrying food for at least 9 days were observed (according to Vickery et al. 1992a). The detectability of sparrows on the ground was probably related to time post-burn and corresponding differences in vegetation density, however, adults carrying food perched on shrubs or fences and were easily observed in any post-burn stage. Time post-burn was recorded for each plot and categorized into $0.5,1.0,1.5$, or 2.5 year classes (Table 1).

\section{Data Analysis}

For territory density, the experimental design was considered to be an incomplete blocks design, in which the blocks were plots and the treatment was years postburn. A search for the Box-Cox variance stabilizing power transformation indicated that the square-root transformation

Table 1. Experimental design used to examine Florida grasshopper sparrow territory density and reproductive success following fire, Avon Park Air Force Range, Highlands County Fla., 1997-1999. The year in which a given years post-burn treatment occurred in a given plot is indicated.

\begin{tabular}{ccccc}
\hline \hline & \multicolumn{5}{c}{ Years post-burn } \\
\cline { 2 - 5 } Plot number & 0.5 & $1.0^{1}$ & 1.5 & 2.5 \\
\hline 1 & 1998 & - & 1997,1999 & - \\
2 & 1999 & - & 1997 & 1998 \\
3 & 1997 & 1999 & 1998 & - \\
4 & 1997 & - & 1998 & 1999 \\
5 & 1997 & - & 1998 & 1999 \\
6 & 1999 & - & 1997 & 1998 \\
7 & 1997 & 1999 & 1998 & 1998 \\
8 & 1999 & - & 1997 & 1999 \\
9 & 1997 & - & 1998 & - \\
10 & 1998 & - & 1997,1999 & - \\
11 & 1997 & 1999 & 1997,1999 & - \\
12 & 1998 & - & 1998 & \\
\hline
\end{tabular}

${ }^{1}$ Burned during an ordnance-ignited wildfire on 29 June 1998. 
induced homoscedasticity. Therefore, it was assumed that the number of territories followed a Poisson distribution, and generalized linear mixed model (GLMM) methodology, as can be implemented in the NLMIXED procedure (SAS Inst., Inc. 1999), was used. The Poisson error distribution and log link were specified for the number of territories per plot, and the offset was specified as the log of plot size.

The GLMM methodology, implemented in PROC NLMIXED in the SAS System (SAS Inst. Inc. 1999), also was used to analyze reproductive success. A logit link and binomial error distribution were specified for the number of territories with successful males for a given plot. Fixed years post-burn effects and random plot-specific effects were included in the linear predictor. If random plot-specific effects appeared negligible, then the simple GLM was fitted in PROC GENMOD (SAS Inst. Inc. 1999). If the global test for years postburn was significant then tests of differences in counts between pairs of years post-burn levels were performed: if random plot effects appeared negligible, then Fishers's exact test was performed for each pair of years post-burn levels.

To graphically examine the possibly nonlinear relationship between reproductive success and territory density, residuals from the analysis of reproductive success were plotted against the residuals from the analysis of density, and a nonparametric smoothed curve (LOESS) was fitted. To statistically test for a relationship between reproductive success and density, hierarchical fixed effects terms for a quintic trend in density were added to the linear predictor in the GLM for reproductive success, and Type 1 hypothesis tests of the fixed effects were performed.

\section{Results and Discussion}

We found no evidence that Florida grasshopper sparrow territory density depended on years post-burn up to 2.5 years $\left(X^{2}=0.830, \mathrm{DF}=3, \mathrm{P}=0.842\right.$ for a Wald test of the years post-burn effect) (Table 2, Fig. 1). Anecdotal accounts indicate higher densities of Florida grasshopper sparrows at recently burned (within 2.5 years) locations (Smith 1968, Delany and Cox 1986). Studies that have quantified habitat selection in relation to time post-burn have found Florida grasshopper sparrow densities ranged from 0.05-0.75 territories/ha during the first year following fire, and decreased to $0.01-0.18$ territories/ha during the subsequent 1.5 years
Table 2. Predicted values of Florida grasshopper sparrow territories per ha at years post-burn (back-transformed scale), Avon Park Air Force Range, Fla., 1997-1999.

\begin{tabular}{|c|c|c|c|c|c|c|c|}
\hline \multirow{2}{*}{$\begin{array}{l}\text { Years } \\
\text { post-burn }\end{array}$} & \multirow[b]{2}{*}{ Mean } & \multirow[b]{2}{*}{$\mathrm{SE}^{1}$} & \multicolumn{2}{|c|}{$95 \%$ CI limits } & \multicolumn{3}{|c|}{$\begin{array}{l}\text { P-value for } \mathrm{H}_{\mathrm{o}} \text { : pair of years-post burn } \\
\text { means are equal }\end{array}$} \\
\hline & & & Lower & Upper & 1.0 & 1.5 & 2.5 \\
\hline 0.5 & 0.20 & 0.050 & 0.113 & 0.344 & 0.77 & 0.59 & 0.50 \\
\hline 1.0 & 0.22 & 0.099 & 0.085 & 0.594 & - & 0.56 & 0.50 \\
\hline 1.5 & 0.17 & 0.043 & 0.099 & 0.300 & - & - & 0.77 \\
\hline 2.5 & 0.16 & 0.053 & 0.074 & 0.330 & - & - & - \\
\hline
\end{tabular}

Obtained by application of the delta method (Seber 1982).
(Walsh et al. 1995, Shriver and Vickery 2001). Walsh et al. (1995) speculated that density changed because young of the year birds dispersed to more suitable, recently burned locations. Increased shrub and saw palmetto growth with the exclusion of fire may eventually allow vegetation to reach a dense successional stage unusable by Florida grasshopper sparrows (Delany et al. 1985). Florida grasshopper sparrow density ( 0.22 territories/ha or less) was lower than most ranges reported for other subspecies (0.21-1.30 territories/ha, in grasslands) (reviewed in Vickery 1996). The sparrow is at the edge of the species' range and may therefore exhibit relatively low abundance (Curnutt et al. 1996).
The plot variance component was negli- gible in the fit of the GLMM for reproductive success $(P=1.00)$. Based on the simple GLM, Florida grasshopper sparrow reproductive success depended on years post-burn $(\mathrm{P}=0.0036)$. The probability of reproductive success was higher 0.5 year post-burn than at 1.5 years post-burn $(\mathrm{P}<$ $0.05)$ and 2.5 years post-burn $(\mathrm{P}<0.01)$. No other pairwise comparisons between years post-burn were significant $(\mathrm{P}>0.27$ for each pairwise comparison) (Table 3, found increased reproductive success for Florida grasshopper sparrows on our study Johnson and Temple (1986) reported higher reproductive success for grasshopper sparrows (A. s. pratensis Vieillot) in recently Fig. 2). Shriver and Vickery (2001) also area in plots 0.5 year following fire.

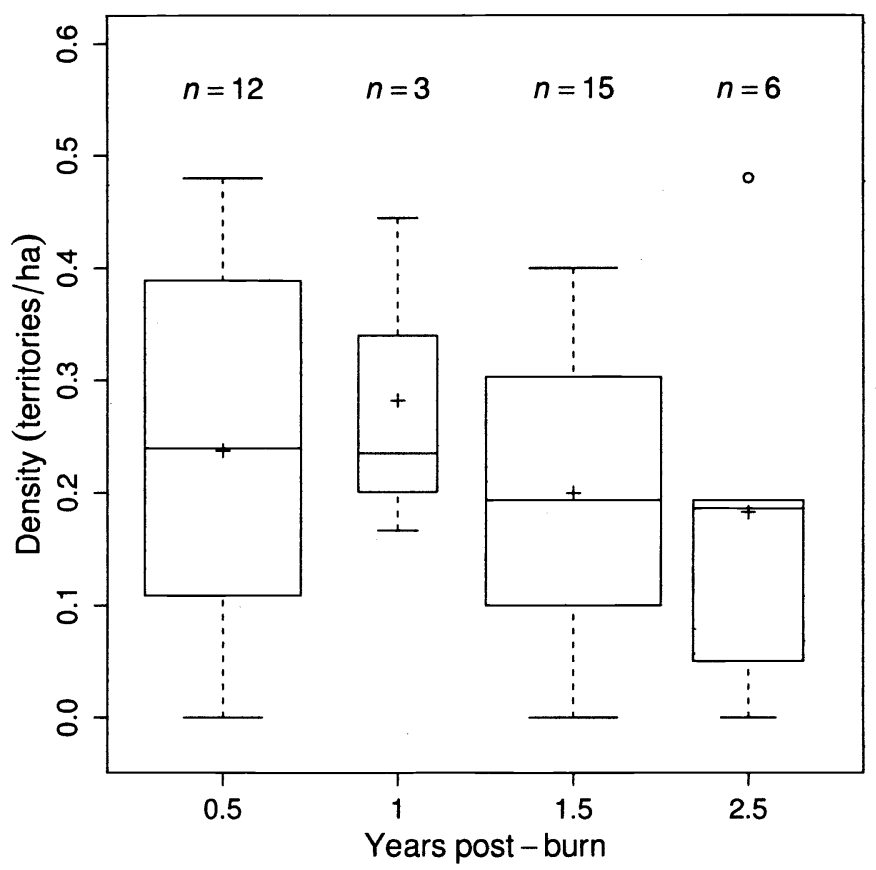

Fig. 1. Boxplots of Florida grasshopper sparrow density ( $n=$ number of plots), Avon Park Air Force Range, Highlands County, Fla., 1997-1999. Study plot and year, and thus possible correlation among observations, were ignored. The bottom and top edges of the box plots are located at the sample $25^{\text {th }}$ and $75^{\text {th }}$ percentiles; the center horizontal line is located at the sample median; the plus symbol is the sample mean; the vertical lines extend to the range of the data, to a distance of at most 1.5 interquartile ranges from the box; and values more extreme than 1.5 interquartile ranges from the box are denoted by circles. Widths of boxes are proportional to the square-root of the number of observations. 
Table 3. Proportion of Florida grasshopper sparrow territories with reproductive success at years post-burn, Avon Park Air Force Range, Fla., 1997-1999.

\begin{tabular}{|c|c|c|c|c|c|c|c|}
\hline \multirow{2}{*}{$\begin{array}{l}\text { Years } \\
\text { post-burn }\end{array}$} & \multirow[b]{2}{*}{$\mathrm{n}$} & \multirow[b]{2}{*}{ Estimate } & \multicolumn{2}{|c|}{$95 \%$ CI limits } & \multicolumn{3}{|c|}{$\underline{P}$-value for pairwise Fisher's exact test } \\
\hline & & & Lower & Upper & 1.0 & 1.5 & 2.5 \\
\hline 0.5 & 32 & 0.38 & 0.211 & 0.563 & 0.278 & 0.048 & 0.010 \\
\hline 1.0 & 4 & 0.00 & 0.000 & 0.527 & - & 1.000 & 1.000 \\
\hline 1.5 & 35 & 0.14 & 0.048 & 0.303 & - & - & 0.304 \\
\hline 2.5 & 13 & 0.00 & 0.000 & 0.206 & - & - & - \\
\hline
\end{tabular}

burned (1 year post-burn) grasslands in Minnesota. The overall reproductive success during our study was only $20 \%$ (17 of 84 males successfully reproduced). Using the same index, Delisle and Savidge (1996) estimated $52 \%$ reproductive success for grasshopper sparrows in Nebraska, and Vickery et. al. (1992a) estimated 40-50\% reproductive success in Maine.

Higher reproductive success in pastures 0.5 year post-burn may be related to structural characteristics of potential nest sites available for this ground-nesting bird. Features of the nest site may have important implications for reproductive success by providing concealment from predators (Martin 1993, but see Vickery et al. 1992c) and ameliorating the microclimate at nests (With and Webb 1993). Small clumps of dense vegetation slightly larger than nest diameter (about $12.3 \mathrm{~cm}$ ) within more open patches (at least $4 \mathrm{~m}$ in diameter) were important factors influencing Florida grasshopper sparrow nest site selection on the study area (Delany and Linda 1998a). Changes in vegetation density and bare-ground cover among nest sites corresponded with an increase in plant material with time following fire (Delany and Linda 1998b). Optimal combinations of vegetation density for nest shielding and bare-ground cover for nest access, predator distraction displays, and foraging may occur 0.5 year after fire.

Type 1 hypothesis tests of linear, quadratic, cubic, and quintic terms in density in a GLM for reproductive success were nonsignificant ( $P>0.41$ for each term). Inspection of the plot of residuals from the analysis of reproductive success (without density terms in the model) versus residuals from the analysis of density indicated oscillation about zero (Fig. 3). Therefore, no simple trend or highly significant polynomial relationship between an individual's reproductive success and territory density was indicated. Our results support contentions that population density may not be a reliable indicator of habitat quality (Van Horne 1983), or the reproductive success of emberizine sparrows (Vickery et al. 1992b).

\section{Conclusions and Management Implications}

Our study encompassed the entire burn cycle at this location and results suggest increased reproductive success of Florida grasshopper sparrows at a population level 0.5 year following fire. However, our results should be viewed with caution. Data were obtained from only one population, and there was some confounding between calendar year and years postburn. The 2.5 years post-burn treatment occurred only in 1998 and 1999, and the 1.0 years post-burn treatment occurred only in 1999. Also, the sample size for the

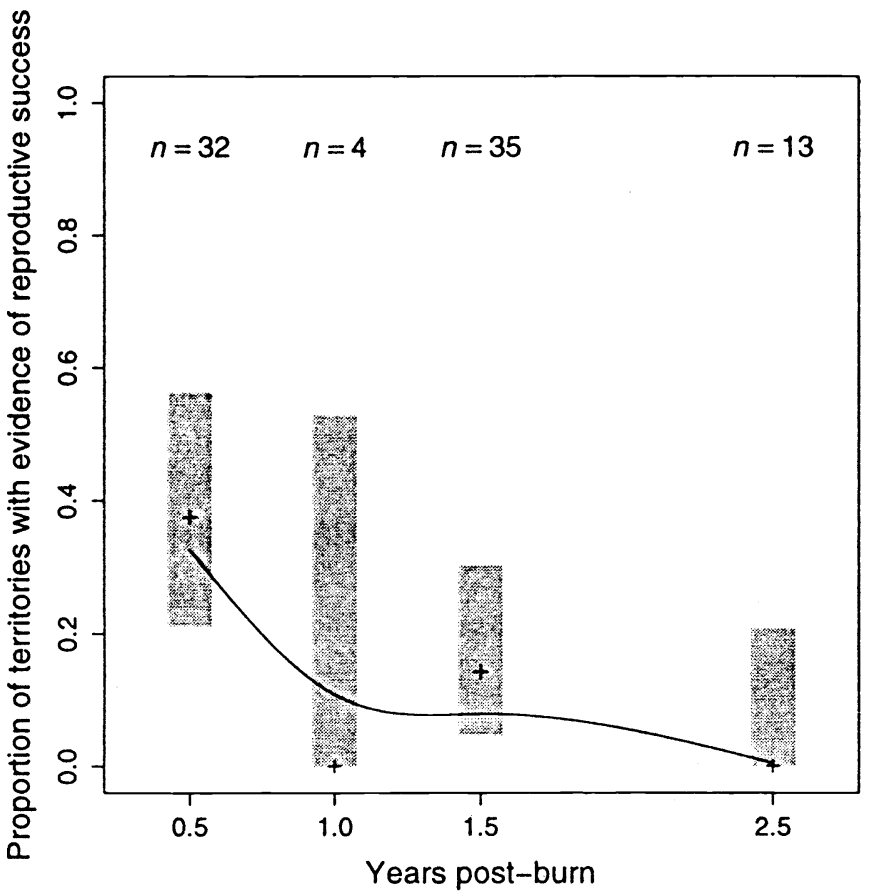

Fig. 2. Proportion of Florida grasshopper sparrow territories with reproductive success at years post-burn, Avon Park Air Force Range, Highlands County, Fla., 1997-1999. Plus symbols indicate empirical proportions, grey bars indicate exact $95 \%$ confidence intervals for proportions, and curved line indicates the fit of a smoothed curve (the cubic smoothing spline) to the empirical proportions.

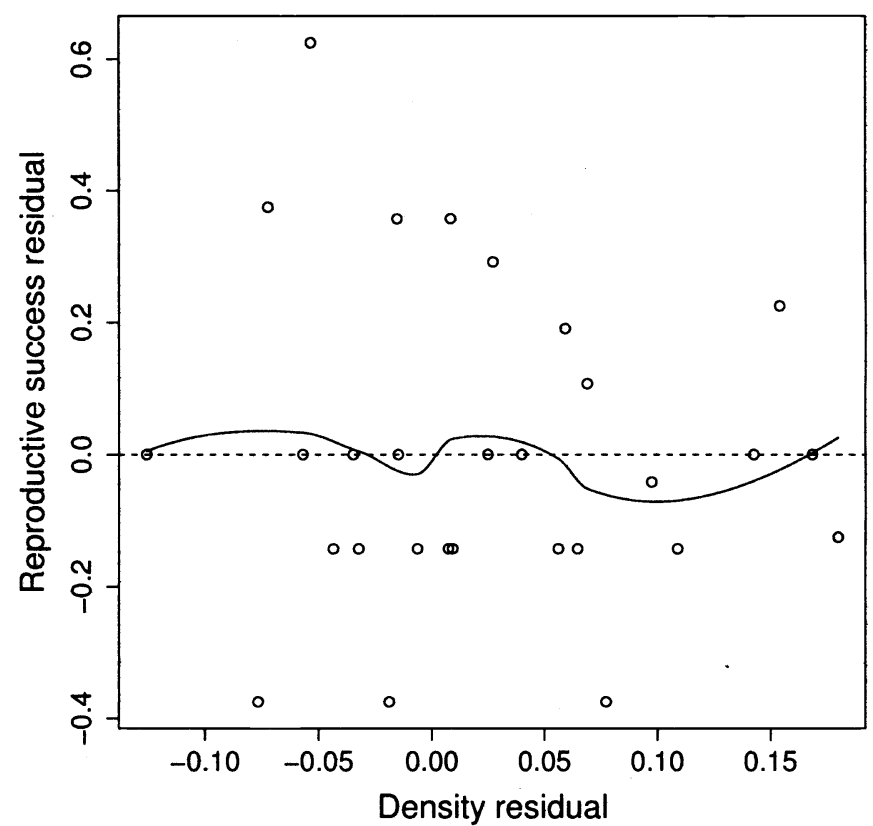

Fig. 3. Plot of residuals from the analysis of Florida grasshopper sparrow reproductive success versus residuals from the analysis of territory density, Avon Park Air Force Range, Highlands County, Fla., 1997-1999. Curve indicates nonparametric smooth fit (LOESS, with span $=3 / 4$ ). 
1.0 year post-burn treatment included only 3 plots.

Appropriate habitat management for most grasshopper sparrow populations appears to be the maintenance of grasslands that are frequently burned and devoid of forest edges (Johnson and Temple 1986, Delisle and Savidge 1996, Vickery 1996). Prescribed burning during the winter (December-March) at 2-3 year intervals seems to maintain suitable habitat for the Florida subspecies (Delany and Cox 1986). Winter burning also avoids potential nest loss from fires during the late-March through July breeding season. However, winter fires may alter the composition of Florida's dry prairies by increasing woody biomass and reducing native grasses and forbs (U.S. Fish and Wildlife Service 1999). Wiregrass normally does not flower unless burned during late-spring or summer, and some prairie forbs such as deer tongue (Carphephorus paniculatus Gmel.) and yellow bachelor's button (Polygala rugelii Chapm.) flower more conspicuously (Abrahamson 1984). Florida's prairie ecosystem has probably been maintained by a frequent fire cycle (1-4 years) caused by summer (May-September) thunderstorms (Abrahamson and Hartnett 1990, Chen and Gerber 1990). Prescribed burns that mimic a natural fire regime may better sustain this pyrogenic plant community. Florida grasshopper sparrows are probably adapted to summer fires, and may exhibit increased densities and a prolonged breeding season following such burns (Shriver et al. 1996, Shriver et al. 1999). Studies of Florida grasshopper sparrow abundance and productivity are needed to determine the effects of the seasonality of fire.

\section{Literature Cited}

Abrahamson, W.G. 1984. Species response to fire on the Florida Lake Wales Ridge. Amer. J. Bot. 71:35-43.

Abrahamson, W.G. and D.C. Hartnett. 1990. Pine Flatwoods and Dry Prairies. p. 103-150 In: R. L. Myers and J. J. Ewel (eds.) Ecosystems of Florida. Univ. Central Fla. Press, Orlando, Fla.

Carter, L.J., D. Lewis, L. Crockett, and J. Vega. 1989. Soil survey of Highlands County, Florida. USDA Soil Conserv. Serv., Sebring, Fla.

Chen, E. and J.F. Gerber. 1990. Climate. p. 11-13 In: R. L. Myers and J. J. Ewel (eds.) Ecosystems of Florida. Univ. Central Fla. Press, Orlando, Fla.

Curnutt, J.L., S.L. Pimm, and B.A. Maurer. 1996. Population variability of sparrows in space and time. Oikos 76:131-144.
Delany, M.F. and J.A. Cox. 1986. Florida grasshopper sparrow breeding distribution and abundance in 1984. Fla. Field Nat. 14:100-104.

Delany, M.F. and S.B. Linda. 1994. Characteristics of occupied and abandoned Florida grasshopper sparrow territories. Fla. Field Nat. 22:106-109.

Delany, M.F. and S.B. Linda. 1998a. Characteristics of Florida grasshopper sparrow nests. Wilson Bull. 110:136-139.

Delany, M.F. and S.B. Linda. 1998b. Nesting habitat of Florida grasshopper sparrows at Avon Park Air Force Range. Fla. Field Nat. 26:33-39.

Delany, M.F., H.M. Stevenson, and $R$. McCracken. 1985. Distribution, abundance, and habitat of Florida grasshopper sparrows. J. Wildl. Mgt. 49:626-631.

Delany, M.F., P.B. Walsh, B. Pranty, and D.W. Perkins. 1999. A previously unknown population of Florida grasshopper sparrows on Avon Park Air Force Range. Fla. Field Nat. 27:52-56.

Delisle, J.M. and J.A. Savidge. 1996. Reproductive success of grasshopper sparrows in relation to edge. Prairie Nat. 28:107-113.

ESRI. 1990. ArcView 3.0 GIS software. Environmental Systems Research Institute Inc. Redlands, Calif.

International Bird Census Committee. 1970. An international standard for a mapping method in bird census work recommended by the International Bird Census Committee. Aud. Field Notes 24:722-726.

Johnson, R.G. and S.A. Temple. 1986. Assessing habitat quality for birds nesting in fragmented tallgrass prairies. p. 245-249 In: J. Verner, M. L. Morrison, and C. J. Ralphs (eds.) Wildlife 2000: Modeling habitat relationships of terrestrial vertebrates. Univ. Wisc. Press, Madison, Wisc.

Lewis, C.E. 1964. Forage response to month of burning. U.S. For. Serv. Res. Note SE-35, Asheville, N.C.

Martin, T.E. 1993. Nest predation and nest sites, new perspectives on old patterns. BioSci. 43:523-532.

Milleson, J.F., R.L. Goodrick, and J.A. Van Arman. 1980. Plant communities of the Kissimmee River Valley. South Fla. Water Mgt. Dist. Tech. Pub. 80-7.

Peterjohn, B.G. and J.R. Sauer. 1999. Population status of North American grassland birds from the North American breeding bird survey, 1966-1996. Stud. in Avian Biol. 19:27-44.

SAS Inst., Inc. 1999. SAS OnlineDoc ${ }^{\mathrm{TM}}$ Version 7-1. SAS Institute Inc., Cary, NC.

Seber, G.A.F. 1982. The estimation of animal abundance and related parameters. Charles Griffin and Co., London and High Wycombe.

Shriver, W.G. and P.D. Vickery. 1999. Aerial assessment of potential Florida grasshopper sparrow habitat: conservation in a fragmented landscape. Fla. Field Nat. 27:1-9.

Shriver, W.G. and P.D. Vickery. 2001. Response of breeding Florida grasshopper and Bachman's sparrows to winter prescribed burning. J. Wildl. Mgt. 65:470-475.
Shriver, W.G., P.D. Vickery, and S.A. Hedges. 1996. Effects of summer burns on Florida grasshopper sparrows. Fla. Field Nat. 24:68-73.

Shriver, W.G., P.D. Vickery, and D.W. Perkins. 1999. The effects of summer burns on breeding Florida grasshopper and Bachman's sparrows. Stud. in Avian Biol. 19:144-148.

Smith, R.L. 1968. Grasshopper sparrow. p. 725-745 In: Life histories of North American cardinals, grosbeaks, buntings, towhees, finches, sparrows and allies, A. C. Bent (ed.). Pt. 2. U.S. Natl. Mus. Bull. 237. Washington D. C.

U.S. Fish and Wildlife Service. 1988. Recovery plan for Florida grasshopper sparrow. U.S. Fish and Wildlife Service, Atlanta, Ga.

U.S. Fish and Wildlife Service. 1999. Dry Prairie p. 279-339 In: South Florida multispecies recovery plan. U.S. Fish and Wildlife Service, Atlanta, Ga.

Van Horne, B. 1983. Density as a misleading indicator of habitat quality. J. Wildl. Mgt. 47:893-901.

Vickery, P.D. 1996. Grasshopper sparrow (Ammodramus savannarum). In: The birds of North America, number 239. A. Poole and F. Gill (eds.). Acad Natural Sci., Philadelphia, Penn., and Amer. Ornith. Union, Washington, D.C.

Vickery, P.D., M. Hunter, Jr., and J.V. Wells. 1992a. Use of a new reproductive index to evaluate relationship between habitat quality and breeding success. Auk 109:697-705.

Vickery, P.D., M. Hunter, Jr., and J.V. Wells. 1992b. Is density an indicator of breeding success? Auk 109:706-710.

Vickery, P.D., M.L. Hunter, Jr., and J.V. Wells. 1992c. Evidence of incidental nest predation and its effects on nests of threatened grassland birds. Oikos 63:281-288.

Walsh, P.B., D.A. Darrow, and J.G. Dyess. 1995. Habitat selection by Florida grasshopper sparrows in response to fire. Proc. Annu. Conf. Southeast. Assoc. Fish and Wildl. Agencies 49:340-347.

With, K.A., and D.R. Webb. 1993. Microclimate of ground nests: relative importance of radiative cover and wind breaks for three grassland species. Condor 95:401-413. 